\title{
PRODUCTION OF ALKALINE PHOSPHATASE FROM A FACULTATIVE PSYCHROPHILIC PSEUDOMONAS SP. MRLBA1 ISOLATED FROM PASSU GLACIER, PAKISTAN
}

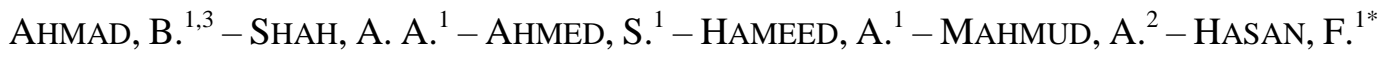 \\ ${ }^{1}$ Department of Microbiology, Quaid-i-Azam University \\ 45320 Islamabad, Pakistan \\ ${ }^{2}$ National Institute of Pakistan Studies, Quaid-i-Azam University \\ 45320 Islamabad, Pakistan \\ ${ }^{3}$ Department of Biotechnology, International Islamic University \\ 44000 Islamabad, Pakistan \\ *Corresponding author \\ e-mail:farihahasan@yahoo.com \\ (Received $29^{\text {th }}$ Jun 2017; accepted $19^{\text {th }}$ Oct 2017)
}

\begin{abstract}
Among our collection of psychrophilic bacteria from various non-polar glaciers, the present study involves the study of the ability of the psychrophilic bacterial strains, isolated from Passu Glacier, Pakistan, to produce thermolabile alkaline phosphatase extracellularly as well as intracellularly. The biophysio-chemical characteristics and 16S rRNA signatures of the isolate MRLBA1 were similar to the members of genus Pseudomonas. This rod shaped MRLBA1 isolated from glacial ice exhibited aerobic growth cycle with cardinal limits of $\mathrm{pH} ; 4-11$ and temperature; $2-30^{\circ} \mathrm{C}$. The strain showed highest extracellular alkaline phosphatase activity at $\mathrm{pH} 8.0$ and $18^{\circ} \mathrm{C}$ when inoculated with $24 \mathrm{~h}$ old inoculum $(5 \%)$, after $48 \mathrm{~h}$ of incubation in shake flask at $150 \mathrm{rpm}$. The strain's targeting mechanism of alkaline phosphatase at cell membrane as well as in the extracellular medium is interesting. The results demonstrated that alkaline phosphatase being thermolabile, acts as a stress protein also in addition to harvesting the energy directly in carbon deficient ice.
\end{abstract}

Keywords: psychrotrophs, thermolabile activity, mountain glaciers, phosphomonoesterase

\section{Introduction}

Non-polar glaciers are analogous to other frozen bodies of the crust and harbor simple life entombed since ages. Facultatively psychrophilic bacteria have been reported in normal flora of glaciers which play major role in harvesting energy through re-designing their metabolic machinery (Morita and Moyer, 2001). Glacial ice represents a unique niche with variant aspects for physiology of bacteria including scarce nutrients, $\mathrm{pH}$, temperature, properties of water and other physico-chemical parameters. A long term exposure and adaptability of these bacteria provide with modified pattern of physiology though with similar biochemistry. Psychrophilic microorganisms produce enzymes which are adapted to be active at low temperatures. As compared to their mesophilic counterparts, they display an increased catalytic efficiency over a temperature range of about $0-30^{\circ} \mathrm{C}$ and a high thermosensitivity. These enzymes have a great potential to be used in biotechnology industry, e.g. in the detergent and food industries, production of fine chemicals and in bioremediation processes (Gerday et al., 1997). Contrary to primary metabolites (proteases, lipases, nucleases), phosphate cannot be synthesized and must be obtained from nucleic acids, phosphorylated sugars and proteins etc. The nutrient deficient ecosystems stipulate the 
release of Pi through hydrolysis of phosphate esters using phosphatises (De Prada et al., 1996).

In an intensive competition for phosphate, bacteria express enhanced activities of phosphatases. We propose that the same phosphatase under various inductions like stress of temperature is processed and targeted differently, as suggested in previous reports (De Prada et al., 1996; Vincent et al., 1992). There is wide variation among phosphatases depending on specificity of substrate, temperature and $\mathrm{pH}$ range, and/or requirement of metal ions (Hong et al., 2007). Periplasmic membrane bound (Baoudene-Assali et al., 1993) and extracellular (Glew and Health, 1971) isozymes of phosphoesterase activity have been reported previously. Phosphatases play major role in ability of a psychrophile to compete at low temperature and attribute in its various commercial applications. Alkaline phosphatase (EC 3.1.3.1) is a cellular metabolite widely distributed in nature from microbes to complex animals. In vitro applications of these enzymes span diagnostics (markers, biosensors), molecular biology (dephosphorylation) and immunology (ELISA), Western blot, nucleic acid hybridization and In-situ hybridization. A heat labile phosphatase will be beneficial in terms of time and shortening of protocols; as robust enzyme without prior thawing procedure before use, or activity silencing steps using heat inactivation (Col et al., 2010).

Lee et al. (2015) reported mAP enzyme as the first thermolabile alkaline phosphatase found in cold-adapted marine metagenomes and expected to be useful for efficient dephosphorylation of linearized DNA. The gene encoding a novel AP was isolated from a metagenomic library constructed with ocean-tidal flat sediments from the west coast of Korea. The amino acid sequence of mAP showed a high degree of similarity to other members of the AP family. Phylogenetic analysis showed mAP to be a member of a recently identified family of PhoX that is different from the classical PhoA (Lewenza et al., 2005) family. The crystal structure of a cold-active alkaline phosphatase from a psychrophile, Shewanella sp. (SCAP), have been determined by Tsuruta et al. (2010). Psychrophiles synthesize cold-active enzymes to sustain their cell cycle, and these enzymes are already used in many biotechnological applications requiring high activity at mild temperatures or fast heat-inactivation rate. Most psychrophilic enzymes optimize a high activity at low temperature at the expense of substrate affinity, therefore reducing the free energy barrier of the transition state (Struvay and Feller, 2012).

Isolate MRLBA1 exhibited robust phosphatase activity which was inactivated completely at $56^{\circ} \mathrm{C}$, suggesting it as a heat labile enzyme. A comprehensive biophysiochemical characterization and identification of Pseudomonas sp. MRLBA1 is presented here. With emphasis on physiological adaptations of this strain under stress conditions, alkaline phosphatase is proposed to be expressed differently and functioning under various inductions, as described here.

\section{Materials and methods}

\section{Sample collection}

Samples of deep ice and melt water were collected in sterile polypropylene bags and bottles aseptically from Passu Glacier (temperature $0^{\circ} \mathrm{C}$, pressure $794 \mathrm{mb}$, located about $2830 \mathrm{~m}$ above sea level) situated at $36^{\circ} 27^{\prime} 21.9 \mathrm{E}$ and $074^{\circ} 52^{\prime} 32.8 \mathrm{~N}$ in Karakoram Range of mountains, Northern Areas of Pakistan. The samples were transported to the laboratory in their intact physical conditions and stored at $-80^{\circ} \mathrm{C}$. 


\section{Isolation and characterization of isolate MRLBAI}

Samples of molten ice and water were serially diluted up to ten fold in normal saline. About $100 \mu 1$ of each dilution was spread on Nutrient agar plates (Oxoid, Basingstoke, UK), which were then, incubated aerobically at 4,10 and $20^{\circ} \mathrm{C}$ for 7 days. A few discrete colonies were inoculated in Nutrient broth and incubated at $20^{\circ} \mathrm{C}$. The isolates were screened for alkaline phosphatase activity intra and extracellularly and the isolate MRLBA1 was selected for further studies.

For morpho-physiological studies, colony morphology (color, shape, elevation, margins, and odor), Gram's staining, optimum temperature, $\mathrm{pH}$, respiration using Gas Generating Kit (Oxoid, UK), growth rate and carbohydrate assimilation using Analytical Profile Index (API® 50CHB, BioMérieux ${ }^{\circledR}$ France) was examined. For biochemical characteristics, the tests were performed following protocols described by Lanyi (1987) and Simbert and Kreig (1994).

\section{Electron microscopy}

Cells grown at log phase under conditions given above were fixed with $3 \%(\mathrm{v} / \mathrm{v})$

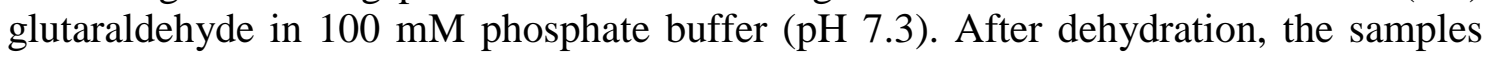
were coated with gold in a sputter-coater (SPI-Module, USA) and examined with a scanning electron microscope (JSM5910, JEOL, Japan).

\section{S rRNA gene sequencing and phylogenetic analysis}

Genomic DNA extraction and amplification of the 16S rRNA gene were done as mentioned previously (Janarthanan and Vincent, 2007) using the set of universal primers; 27F 5'AGAGTTTGATCCTGGCTCAG3' and 1492R 5'TACGGTTACCTTGTTACGACTT3' according to Lane (1991) and Reysenbach et al. (1995). PCR products were sequenced according to the manufacturer's instructions using the ABI PRISM ${ }^{\circledR}$ BigDye $^{\text {TM }}$ Terminator cycle sequencing kit (Applied Biosystems Inc., Warrington, United Kingdom). The nucleotide homology search was performed against the partial 16S rRNA sequences of 1047 base pairs using the nucleotide BLAST program "BLASTn" (Altschul et al., 1997) in non-redundant (nr) data base. The sequences having equal or more than $97 \%$ sequence homology but validated by IJSEM previously were retrieved from the Gene Bank and aligned using Clustal W program (Thompson et al., 1994) in the Molecular Evolutionary Genetics Analysis Program (MEGA) version 4.0.1 (Tamura et al., 2007). The regions in the sequences corresponding to the isolate MRLBA1 sequence were retained and all nonaligned sequence parts were trimmed. This alignment was used to construct a neighbor joining (NJ) tree and finally the maximum parsimony (MP) tree (Eck and Dayhoff, 1966) using the Close-Neighbor-Interchange algorithm (Nei and Kumar, 2000) with random addition of 10 replicates.

\section{Culture conditions for production of phosphatase enzyme}

The cultures were routinely maintained on nutrient agar slants at $4{ }^{\circ} \mathrm{C}$. The production of enzyme was carried out in modified production medium $(0.5 \%$ peptone, $0.2 \%$ glucose, $0.08 \mathrm{M} \mathrm{NaCl}, 0.2 \mathrm{mM} \mathrm{CaCl}_{2}, 0.02 \mathrm{M} \mathrm{NH}_{4} \mathrm{Cl}, 0.02 \mathrm{M} \mathrm{KCl}, 1 \mathrm{mM} \mathrm{MgSO}$ and $0.004 \mathrm{mM} \mathrm{ZnCl} 2)$. Sodium phosphate $(0-200 \mu \mathrm{M})$ and calcium phosphate $(0-50 \mathrm{mM})$ were added in the basal medium to study the regulation of alkaline phosphatase 
production as given below. The effect of $\mathrm{pH}$ on growth and enzyme production was studied by growing cells in basal medium. The $\mathrm{pH}$ of the medium was adjusted to 5-13 using appropriate buffers $(10 \mathrm{mM}$; Dhaked et al., 2005). Growth was measured spectrophotometrically at $600 \mathrm{~nm}$ (Agilent 8354).

\section{Enzyme assay conditions}

Activity of alkaline phosphatase was measured by the method of Dhaked et al. (2005) by measuring the absorbance $\left(\mathrm{OD}_{405}\right)$ to monitor the release of $p$-nitrophenol from $p$-nitrophenyl phosphate (pNPP) as mentioned. Reaction mixture contained $300 \mu 1$ of enzyme diluted in $1 \mathrm{M}$ diethanolamine buffer ( $\mathrm{pH} 9.8$ ), $0.5 \mathrm{mM} \mathrm{MgCl}, 0.5 \mathrm{mM}$ $\mathrm{CaCl}_{2}$ and $150 \mathrm{mM}$-nitrophenyl phosphate (pNPP), in a final volume of $3 \mathrm{ml}$.

The reaction performed at $37^{\circ} \mathrm{C}$ for 30 min was stopped by addition of $50 \mu 1$ of $4 \mathrm{M}$ sodium hydroxide. One unit was defined as the amount of alkaline phosphatase which hydrolysed $1 \mu \mathrm{mol}$ of $p$-nitrophenyl phosphate to $p$-nitrophenol in $1 \mathrm{~min}$ at $\mathrm{pH} 9.8$ and $37^{\circ} \mathrm{C}$. The quantification of enzyme activity $\left(\mathrm{OD}_{405} / \mathrm{OD}_{600}\right)$ was done by standard curve of $p$-nitrophenol $(0-500 \mu \mathrm{M})$ at $405 \mathrm{~nm}$.

\section{Results and discussion}

\section{Isolation and characterization of isolate MRLBA1}

The bacterial colonies appeared on Nutrient agar $(\mathrm{pH} 8.0)$ after incubation at $4{ }^{\circ} \mathrm{C}$ for 16 days. The isolate MRLBA1 formed white, smooth circular colonies. The cells were Gram negative short rods (Fig. 1).

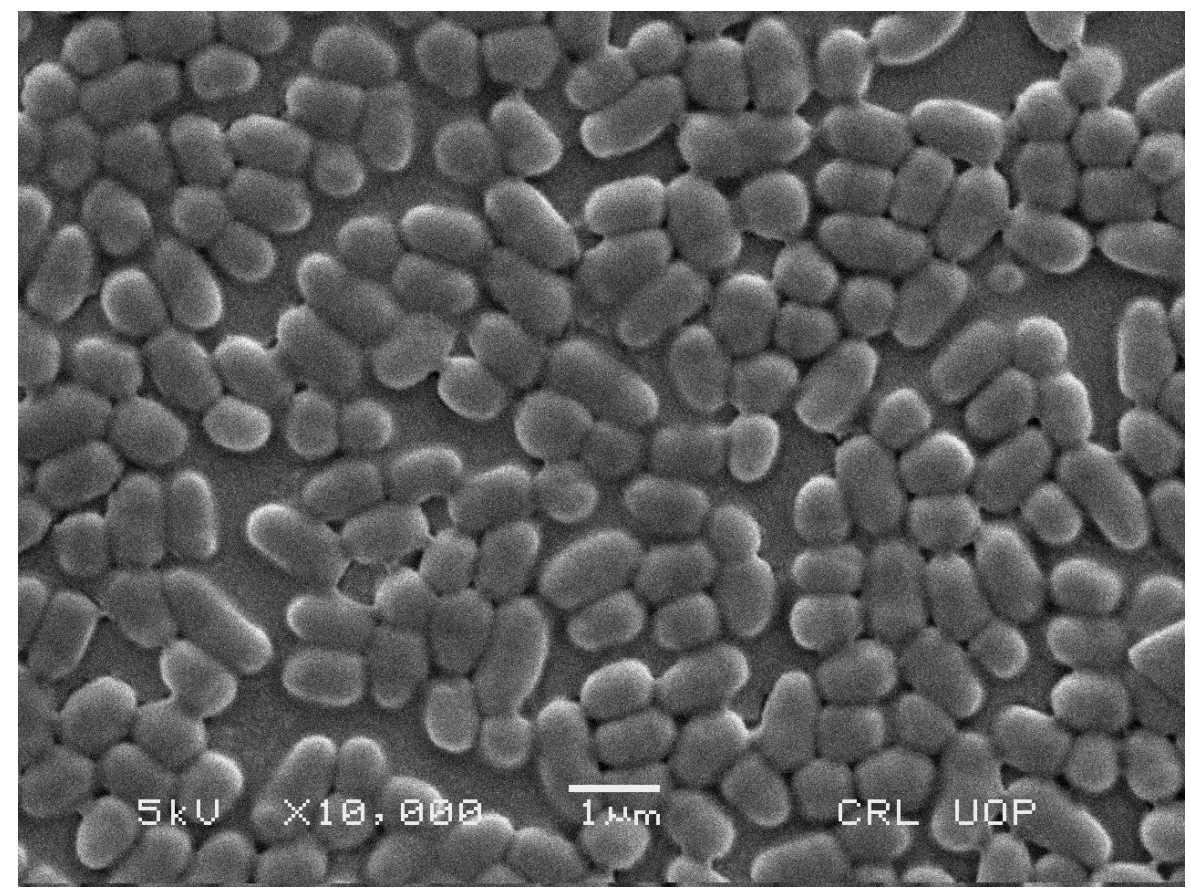

Figure 1. Scanning electron micrograph of cells of Pseudomonas sp. MRLBA1 $(10000 \times$ at 5 $k V)$. The bacteria were harvested in log phase and i). Fixed: (3\% glutaraldehyde prepared in

$0.1 \mathrm{M}$ phosphate buffer ( $\mathrm{pH} 7.3$ ), incubated at $\left.4^{\circ} \mathrm{C}\right)$, Rinsed: (0.1 M phosphate $\left.\mathrm{pH} 7.3\right)$, Dehydrated: (50-90\% gradients of acetone for 10 min each), and dried using $\mathrm{CaCl}_{2}$ 
Obligatory aerobic isolate MRLBA1 was positive for catalase, urease, and Voges Proskauer tests. The isolate exhibited facultatively psychrophilic adjustment of temperature and exhibited respective cardinal and optimum limits of temperatures as: 2$37^{\circ} \mathrm{C} ; 25^{\circ} \mathrm{C}$, and $\mathrm{pH}$ : $4-11 ; 9$ (Fig. 2). The physiological pattern of metabolism and carbon assimilation is given in Tables 1 and 2, respectively.

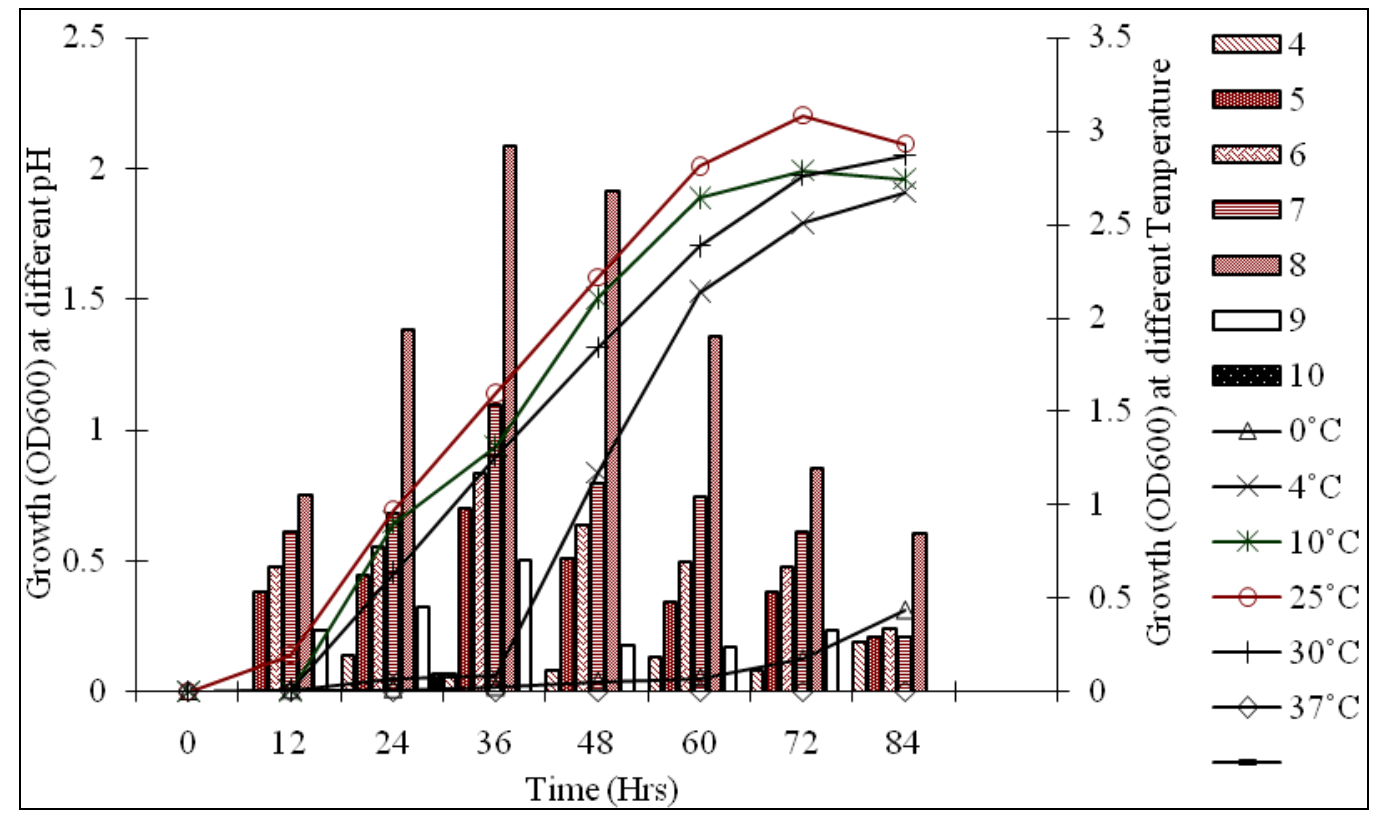

Figure 2. Effect of $p H$ and temperature on the growth of Pseudomonas sp. MRLBA1. The isolate exhibited maximum growth at $\mathrm{pH} 8$ and $25^{\circ} \mathrm{C}$

Table 1. Morpho-physiological and biochemical characteristics of the MRLBA1 isolate

\begin{tabular}{|l|l|}
\hline Colony & White \\
Color & Smooth \\
Margin & - \\
Gram's staining & Rod \\
Cells & - \\
Shape & - \\
Spore & Aerobic \\
Motility & \\
Oxygen utilization & 4 \\
Growth Cardinals & 11 \\
Lower limit & 2 \\
Upper limit & 30 \\
Lower limit $\left({ }^{\circ}\right.$ C) & \\
Upper limit $\left({ }^{\circ}\right.$ C) & + \\
Biochemical & + \\
Alk. Phosphatase & + \\
Amylase & - \\
Catalase & \\
Gelatinase & \\
\hline
\end{tabular}




\begin{tabular}{|l|l|}
\hline Methyl Red & - \\
Nitrate Reductase & - \\
Simmon citrate & - \\
Triple sugar Iron & - \\
Urease & + \\
Voges-Proskauer & + \\
\hline
\end{tabular}

Table 2. Carbon source utilization of the isolate MRLBAI

\begin{tabular}{|c|c|c|c|c|c|c|c|}
\hline Carbon source & Growth & Carbon source & Growth & Carbon source & Growth & Carbon source & Growth \\
\hline Glycerol & + & D-Fructose & + & N-Acetyl & - & Glycogen & - \\
Erythritol & - & D-Mannose & + & Asculin & - & Xylitol & - \\
D-Arabinose & + & Methyl $\alpha$-D & - & Salicin & - & Gentiobiose & + \\
L-Arabinose & + & L-Sarbose & - & D-Cellobiose & + & D-Turanose & - \\
D-Ribose & + & L-Ramnose & - & D-Maltose & + & D-Lyrose & - \\
D-Xylose & + & Dulcitol & - & D-Lactose & + & D-Tagatose & - \\
L-Xylose & - & Inositol & + & D-Mallobiose & + & D-Fucose & + \\
D-Addonitol & - & D-Mannitol & + & D-Sucrose & + & L-Fucose & + \\
Methyl $\beta-$ & - & D-Sorbitol & - & D-Trehalose & + & D-Arabitol & + \\
Dxylpyranoside & & Methyl $\alpha-D$ & - & Inuline & - & L-Arabitol & + \\
D-Glactose & + & Mannpyrunoside & - & & & Potassium & + \\
D-Glucose & + & Amygdaline & - & D-Melezitose & - & Gluconate & + \\
Glycerol & + & Arabutin & - & D-Rafinose & + & Potassium 2- & + \\
& & Letoglutarate & + \\
Erythritol & - & L-Arabinose & + & Amidon & - & Potassium 5- & + \\
D-Arabinose & + & D-Ribose & + & D-Addonitol & - & D-Xylose & + \\
D-Xylose & + & Methyl $\beta-$ & - & L-Arabinose & + & L-Xylose & - \\
L-Xylose & - & D-Glactose & + & D-Ribose & + & D-Addonitol & - \\
Methyl $\beta-$ & - & D-Melezitose & - & D-Turanose & - & & \\
Dxylpyranoside & - & D-Rafinose & + & D-Lyrose & - & \\
D-Glactose & + & & & \\
\hline
\end{tabular}

Expression of proteins from stressed microorganisms entombed away from natural exposure of communities may provide clues of resistance mechanism other than acquired through exposure to antibiotics. Out of seven $\beta$-lactam antibiotics (cell wall synthesis inhibitors and protein synthesis inhibitors), isolate MRLBA1 exhibited sensitivity to neomycin $(18 \mathrm{~mm})$, streptomycin $(22 \mathrm{~mm})$; vancomycin $(11 \mathrm{~mm})$, aztreonam $(24 \mathrm{~mm})$ and tetracycline $(25 \mathrm{~mm})$ but was resistant to penicillin and fosphomycin (Table 3). The additional antibiotic resistance mechanisms regulated through $\mathrm{Mg}^{++}$(Lewenza, 2005), also regulate the secretion and/or activity of alkaline phosphatase. 
Table 3. Antibiotic sensitivity of Pseudomonas sp. MRLBAI

\begin{tabular}{|c|c|c|}
\hline Class & $\begin{array}{c}\text { Antibiotics } \\
\text { (groups) }\end{array}$ & $\begin{array}{c}\text { Zone of inhibition } \\
\text { (MRLBA1) }\end{array}$ \\
\hline \multirow{2}{*}{ Protein synthesis inhibitors } & $\begin{array}{c}\text { Streptomycin } \\
\text { (aminoglycoside) }\end{array}$ & $S(22)$ \\
\hline & $\begin{array}{c}\text { Neomycin } \\
\text { (aminoglycoside) }\end{array}$ & $S(18)$ \\
\hline \multirow{5}{*}{ Cell wall synthesis inhibitors } & $\begin{array}{l}\text { Vancomycin } \\
\text { (glycopeptide) }\end{array}$ & $S(11)$ \\
\hline & $\begin{array}{l}\text { Tetracycline } \\
\text { (glycopeptide) }\end{array}$ & $S(25)$ \\
\hline & $\begin{array}{l}\text { Penicillin } \\
\text { ( } \beta \text {-lactam) }\end{array}$ & $\mathrm{R}$ \\
\hline & $\begin{array}{c}\text { Aztreonam } \\
\text { (monocyclic } \beta \text {-lactam) }\end{array}$ & S (24) \\
\hline & $\begin{array}{c}\text { Fosphomycin } \\
\text { (phosphonomycin) }\end{array}$ & $\mathrm{R}$ \\
\hline
\end{tabular}

$\mathrm{R}=$ resistant, $\mathrm{S}=$ susceptible

\section{S rRNA gene sequencing and phylogenetic analysis}

The 16S rRNA gene sequence and relevant phylogenetic analysis revealed that bacterium MRLBA1 closely resembles genus Pseudomonas (Fig. 3).

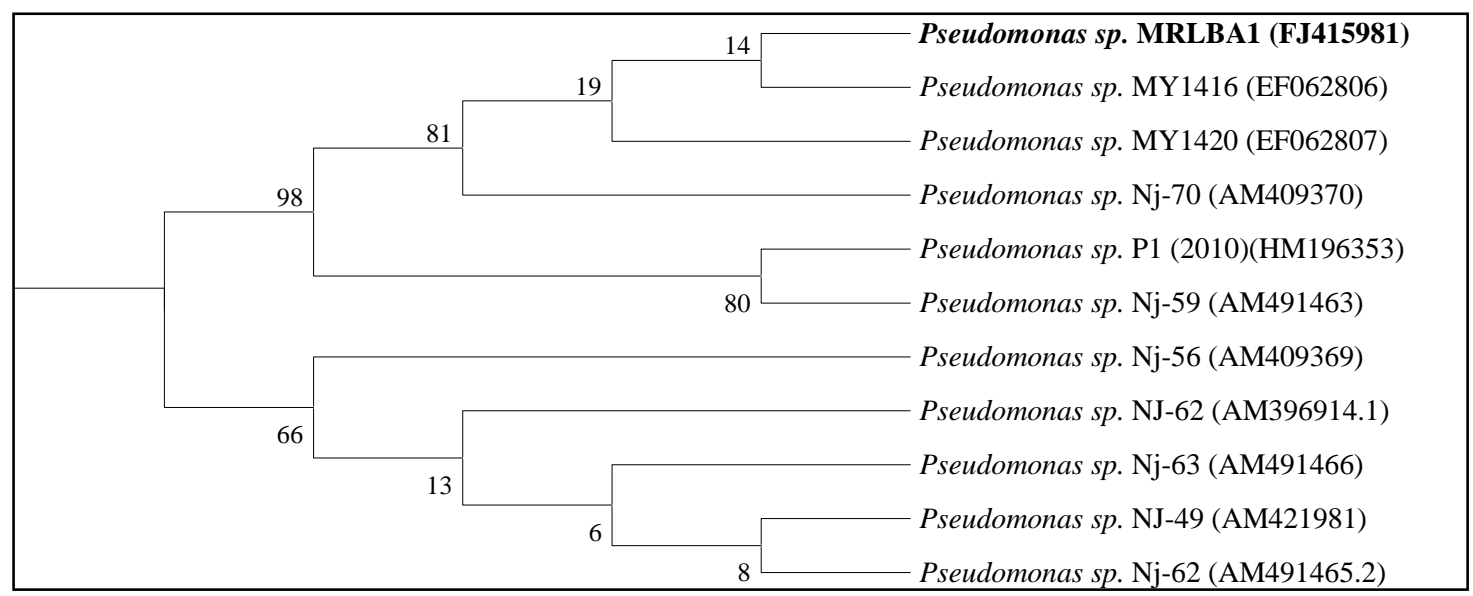

Figure 3. Maximum parsimony phenogram; showing phylogenetic relationship between Pseudomonas sp. MRLBA1 and other related species of the genus Pseudomonas and related reference microorganisms based on the 16s rRNA gene sequence analysis. Bootstrap values (500 replicates) are given at the nods. Tree was generated with 10 replicates using MEGA4 (Close-Neighbor-Interchange algorithm)

The closest relative appears to be Pseudomonas sp. MY1416 with a similarity of $97 \%$ in BLAST analysis. The isolates from polar (Antarctica) and non- polar glaciers like mountain glaciers of Pakistan-China border mostly show novel characteristics, since most of the flora has not been studied in these ecosystems. A small number of similar isolates have been characterized as psychrophilic (Miteva, 2008) including some species 
from Methanococcoides, M. burtonii (Franzmann et al., 1992). Along with other nearby glaciers in the region, like Batura Glacier in Hindu Kush (West Pakistan), Mingyong Glacier in Tibet (North China), Siachen in Himalaya (North-East Kashmir) and the Karakoram glaciers present a huge frozen ancient ecosystem out of pole harboring psychrophilic mode of life. From this isolated cold niche, contrary to other Pseudomonas species under study, the isolate MRLBA1 showed resistance to certain cell wall synthesis inhibitors like penicillin ( $\beta$-lactam) and fosphomycin (phosphonomycin). The finding points out the strain's spatial induction of genetic assembly and/or cell wall divergence.

\section{Growth and enzyme production}

Psychrotolerants with scant energy express alkaline phosphatase as a stress protein to release energy from phosphoanhydrides - the high energy bonds (Seufferheld et al., 2008). Various cold active bacterial species including Arthrobacter sp. (De Prada et al., 1996), Bacillus sphaericus P9 (Dhaked et al., 2005), Pseudomonas aeruginosa (Cheng et al., 1970) and Pseudomonas fluorescens E2 and Pseudomonas sp. 8E3 (Pratt-Lowe et al., 1988) have been used for the production of alkaline phosphatase. The cell mass was observed as 1.81 cells per hour during exponential phase of the bacterium. A plot of growth (O.D) versus time (hours), yielded a typical growth curve with a prolonged lag phase of about $10 \mathrm{~h}$. The exponential phase appeared as a steep curve after $24 \mathrm{~h}$ and lasted up to $36 \mathrm{~h}$ followed by a long stationary phase that lasted up to $120 \mathrm{~h}$ (Fig. 4). The bacterial physiology is not dependent upon the growth rates observed at various temperatures. Also the viable counts have been considered as the crucial parameter to distinguish between psychrophilic and psychrotrophic beings (Feller et al., 1994). A very little activity of alkaline phosphatase $(0.396 \mathrm{U} / \mathrm{ml})$ was found associated with periplasmic space during growth curve.

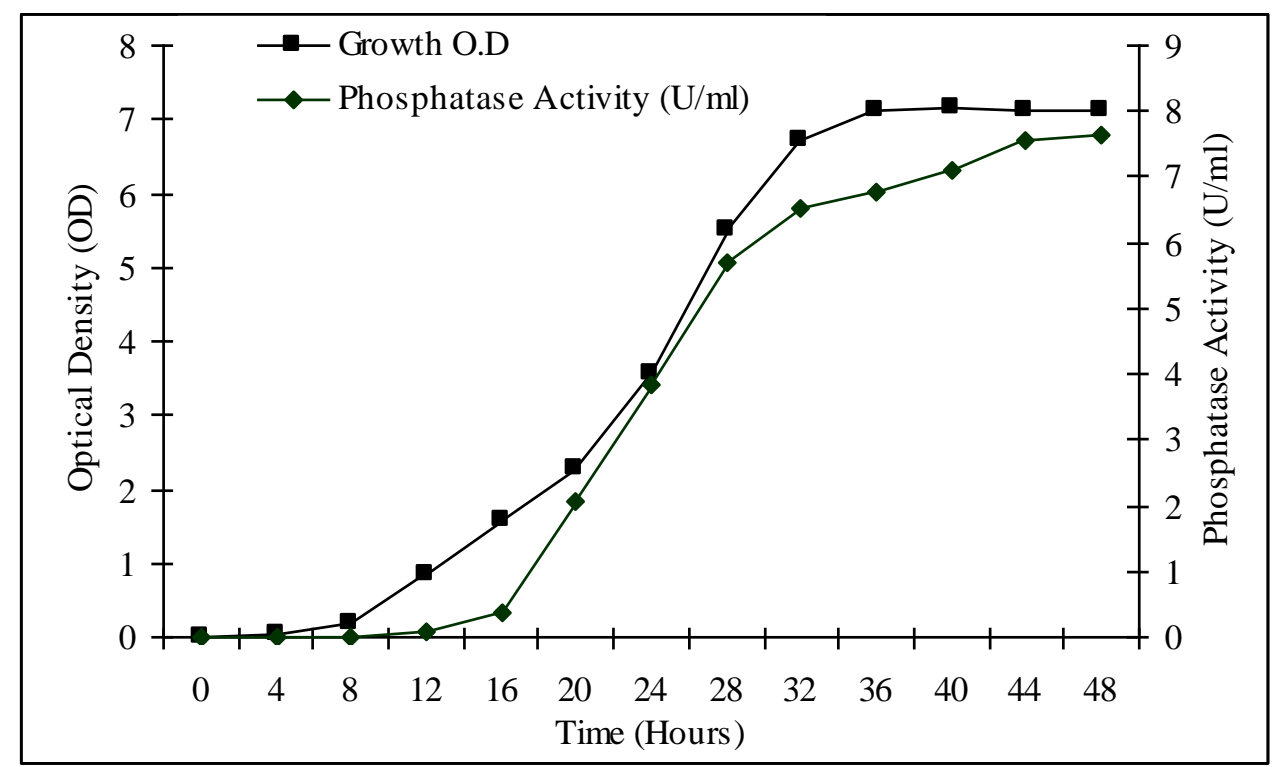

Figure 4. Production of alkaline phosphatase at different stages of bacterial growth. Cells were grown in the basal medium described in the text and growth was monitored by measuring optical density at $600 \mathrm{~nm}$. Phosphatase activity was estimated in the culture supernatant at different stages of growth 


\section{Batch culturing in shake flask}

Pseudomonas sp. MRLBA1 yielded $16 \mathrm{~g}$ of wet cells after $72 \mathrm{~h}$ from 1.61 biomass under optimized conditions.

\section{Effect of $p H$ on the production of alkaline phosphatase}

The Pseudomonas sp. MRLBA1 was capable of growing in the $\mathrm{pH}$ range of 4-11 with maximum growth at $\mathrm{pH}$ 9.0. However, the strain produced alkaline phosphatase optimally at $\mathrm{pH} 8.0$ after $72 \mathrm{~h}$ of incubation at $18^{\circ} \mathrm{C}$ and $150 \mathrm{rpm}$ with specific activity of $57.56 \mathrm{U} / \mathrm{mg}$ protein $(\mathrm{P}<0.0001)$. The production of enzyme (specific activity) was reported as 33.05, 44.32, 47.14, 56.28 and $35.39 \mathrm{U} / \mathrm{mg}$ at $\mathrm{pH} 5.0,6.0,7.0,9.0$ and 10.0, respectively (Fig. 5a).

The production of enzyme significantly decreased on $\mathrm{pH}$ other than optimal value. The production of enzyme was targeted in late stationary and death phase of the growth curve. A very little activity was found attributed to the cell bound during growth cycle of the bacterium (Fig. 5a).

\section{Effect of temperature on the production of alkaline phosphatase}

Optimum alkaline phosphatase was produced $(22.41 \mathrm{U} / \mathrm{ml})$ with specific activity $(53.72 \mathrm{U} / \mathrm{mg})$ at $18^{\circ} \mathrm{C}$ after $48 \mathrm{~h}$ of incubation $(\mathrm{P}<0.0001)$. At lower temperatures i.e. 4,10 and $15^{\circ} \mathrm{C}$, the production of enzyme $(6.73,11.13$ and $14.57 \mathrm{U} / \mathrm{ml})$ with specific activities as $28.56,41.17$ and $45.81 \mathrm{U} / \mathrm{mg}$, respectively (Fig. $5 b$ ). The yield of enzyme was enhanced when harvested cells were temperature shocked at $-70^{\circ} \mathrm{C}$ for $10 \mathrm{~min}$ and harvested again after resuspension in $20 \mathrm{mM}$ Tris $\mathrm{HCl}(\mathrm{pH} \mathrm{8.0;} \mathrm{Fig.} \mathrm{5b).} \mathrm{The} \mathrm{same}$ practice has been adapted by Hong et al. (2007) for E. coli and Cheng et al. (1970) for Pseudomonas aeruginosa to collect the alkaline phosphatase from periplasm.

\section{Effect of incubation period}

The inoculated production medium revealed specific activities of $4.42 \mathrm{U} / \mathrm{mg}(24 \mathrm{~h})$, $54.01 \mathrm{U} / \mathrm{mg}(48 \mathrm{~h})$ and $59.43 \mathrm{U} / \mathrm{mg}$ after $72 \mathrm{~h}$ of incubation at $\mathrm{pH} 8,18^{\circ} \mathrm{C}$ for $72 \mathrm{~h}$ and $150 \mathrm{rpm}(p$ 0.07; Fig. 5c).

\section{Effect of size of inoculum on the production of alkaline phosphatase}

Optimum alkaline phosphatase (specific activity; $77.02 \mathrm{U} / \mathrm{mg}$ ) was produced in case of $5 \%$ inoculum, whereas, in case of $1,10,15$ and $20 \%$ inoculum size, the specific activities were $38.71,32.37,18.85$ and $12.7 \mathrm{U} / \mathrm{mg}$, respectively, with significant value ( $>0.001$; Fig. $5 d$ ). The $\mathrm{pH}$ of the medium increased up to 8.3 starting from initial $\mathrm{pH}$ 8.0.

\section{Effect of age of inoculum on the production of alkaline phosphatase}

Optimum production of alkaline phosphatase $(56.42 \mathrm{U} / \mathrm{mg})$ was observed in production medium inoculated with a $24 \mathrm{~h}$ old inoculum after $48 \mathrm{~h}$ of incubation at $\mathrm{pH}$ $8.0,18^{\circ} \mathrm{C}, 5 \%$ inoculum and $150 \mathrm{rpm}(\mathrm{p}<.001)$. When 12,48 and $72 \mathrm{~h}$ old inocula were used, specific activities of alkaline phosphatase were recorded as 34.19, 39.53.12 and $16.8 \mathrm{U} / \mathrm{mg}$ respectively (Fig. 5e). 
a

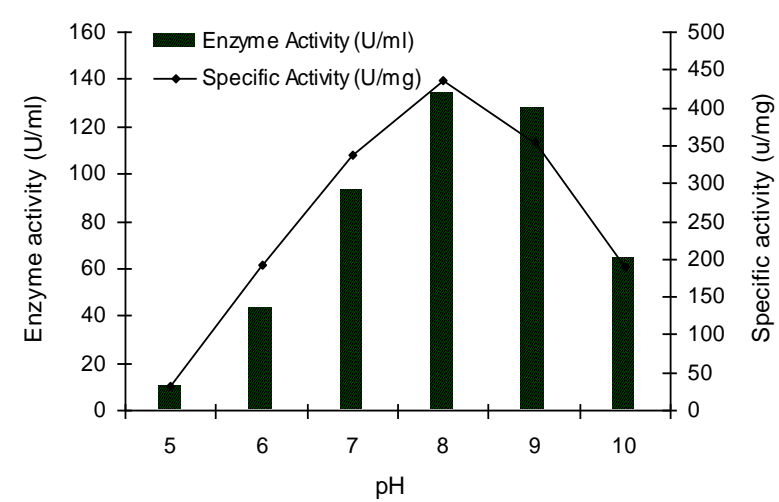

c

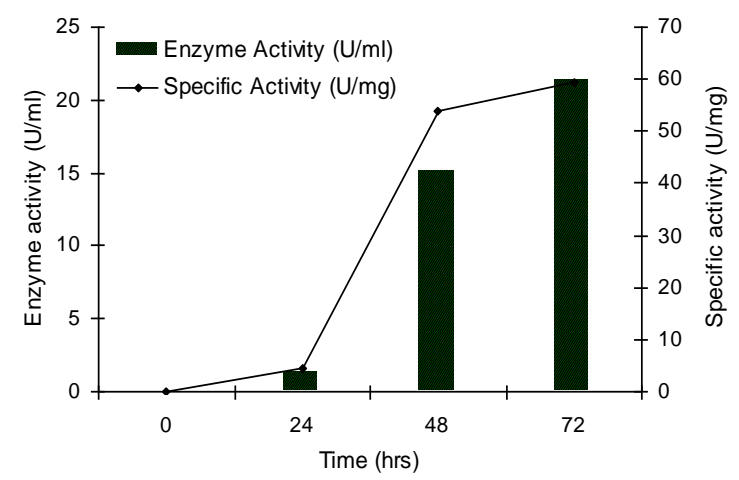

e

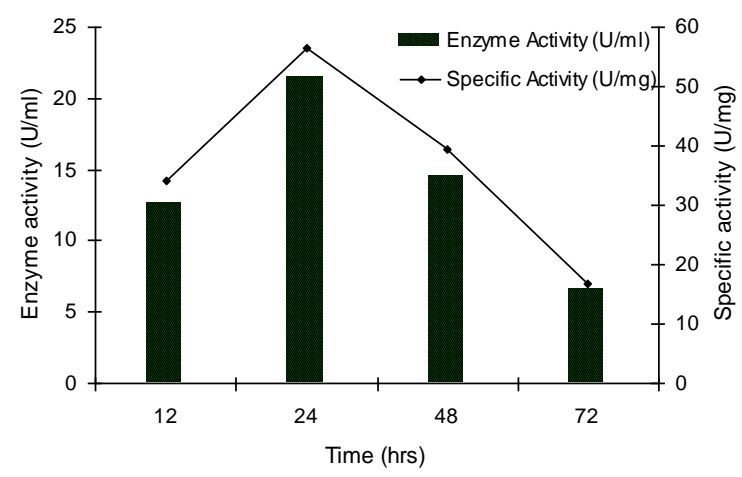

b

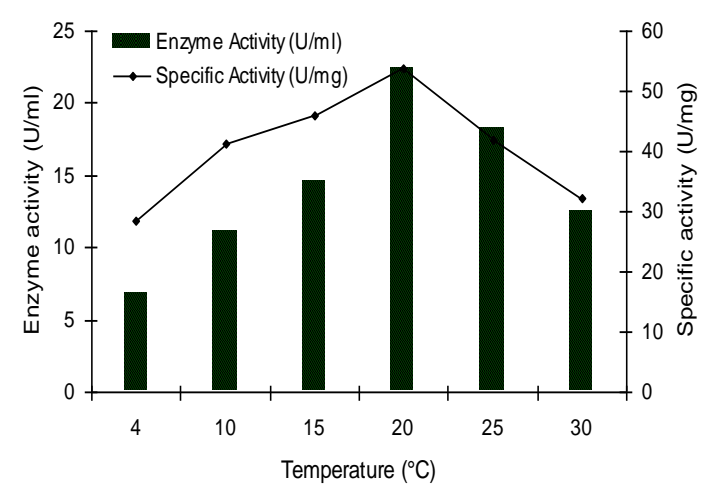

d

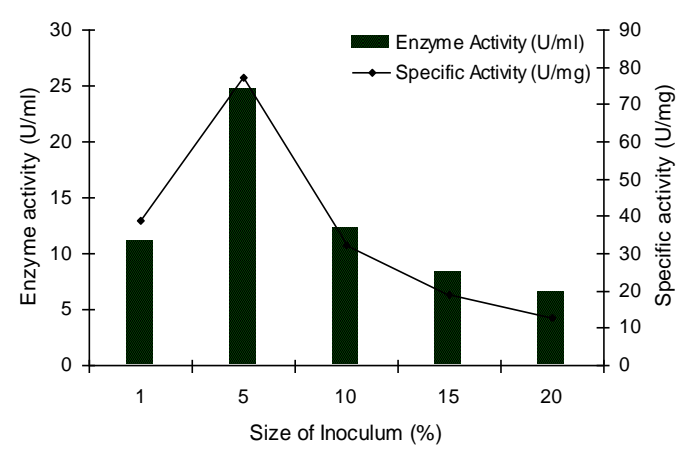

Figure 5. Effect of various parameters (a-e) on the production of alkaline phosphatase. a Effect of $\mathrm{pH}$ on the production of alkaline phosphatase. $b$ Effect of temperature on the production of alkaline phosphatase. $c$ Effect of incubation period on the production of alkaline phosphatase. $d$ Effect of size of inoculum on production of alkaline phosphatase. e Effect of age of inoculum on the production of alkaline phosphatase

\section{Conclusion}

Out of pole, the mountain glaciers are a big resource of psychrophilic microbial diversity and hence and hence for industrial biotechnology. Cold active bacteria from depth of glacial ice could be potential source of enzymes capable of catalysis at lower temperatures. Bacterial metabolism at psychrophilic and/or psychrotrophic range of temperatures depends on the adjustment of their enzymes to work in cold conditions. Hence their enzymes drive the evolutionary adaptations. Psychrophilic enzymes produced by cold-adapted microorganisms display a high catalytic efficiency and may 
be associated with high thermosensitivity. The alkaline phosphatase from Pseudomonas $s p$. MRLBA1 was produced in acceptable range of physiological parameters in accordance with previous reports and implies an uncomplicated commercial source. The characterized production in this investigation is a valuable distinguished information to proceed for pilot scale production of low temperature active alkaline phosphatase.

We want to further this study for further purification and characterization of the heat sensitive activity.

Acknowledgements. Higher Education Commission of Pakistan.

\section{REFERENCES}

[1] Altschul, S. F., Madden, T. L., Schäffer, A. A., Zhang, J., Zhang, Z., Miller, W., Lipman, D. J. (1997): Gapped BLAST and PSI-BLAST: a new generation of protein database search programs. - Nucleic Acids Res 25: 3389-402.

[2] Baoudene-Assali, F., Baratti, J., Michel, G. P. F. (1993): Purification and properties of a phosphate-irrepressible membrane-bound alkaline phosphatase from Zymomonas mobilis. - J Gen Microbiol 139: 29-235.

[3] Cheng, K. J., Ingram, J. M., Costerton, J. W. (1970): Release of alkaline phosphatase from cells of Pseudomonas aeruginosa by manipulation of cation concentration and of pH. - J Bacteriol 104: 748-53.

[4] Col, M., Colak, A., Ertunga, N. S., Yildirim, M., Özel, A. (2010): Cloning, expression and characterization of alkaline phosphatase from a thermophilic bacterium Geobacillus caldoxylosilyticus TK4. - Turk J Biochem 35: 208-14.

[5] De Prada, P., Loveland-Curtze, J., Brenchley, J. E. (1996): Production of two extracellular alkaline phosphatases by a psychrophilic Arthrobacter strain. - Appl Environ Microb 62: 3732-8.

[6] Dhaked, R. K., Alam, S. I., Dixit, A., Singh, L. (2005): Purification and characterization of thermo-labile alkaline phosphatase from an Antarctic psychrotolerant Bacillus sp. P9. - Enzyme Microb Tech 36: 855-61.

[7] Eck, R. V, Dayhoff, M. O. (1966): Atlas of Protein Sequence and Structure. - National Biomedical Research Foundation, Silver Springs, Maryland.

[8] Feller, G., Nrinx, E., Aprigny, J. L., Zekhinini, Z., Swings, J., Gerday, C. (1994): Temperature dependence of growth, enzyme secretion and activity of psychrophilic Antarctic bacteria. - Appl Microbiol Biotechnol 41: 477-9.

[9] Miteva V. (2008): Bacteria in Snow and Glacier Ice. - In: Margesin, R. et al. (eds). Psychrophiles: From Biodiversity to Biotechnology. Springer, Berlin, Heidelberg.

[10] Franzmann, P. D., Springer, N., Ludwig, W., Conway, D. M. E., Rhode, M. A. (1992): Methanogenic archaeon from Ace Lake, Antarctica: Methanococciodes burtonii sp. nov. - Syst Appl Microbiol 15: 573-81.

[11] Gerday, C., Aittaleb, M., Arpigny, J. L., Baise, E., Chessa, J. P., Garsoux, G., Petrescu, I., Feller, G. (1997): Psychrophilic enzymes: a thermodynamic challenge. - Biochim Biophys Acta 17: 119-31.

[12] Glew, R. H, Heath, E. C. (1971): Studies on the extracellular alkaline phosphatase of Micrococcus sodonensis. I. Isolation and characterization. - J Biol Chem 246: 1556-65.

[13] Hong, T., Kong, A., Lam, J., Young, L (2007): Periplasmic alkaline phosphatase activity and abundance in Escherichia coli B23 and C29 during exponential and stationary phase. - J Exper Microbiol Immunol 1: 8-13.

[14] Janarthanan, S., Vincent, S. (2007): Practical Biotechnology: Methods and Protocols. University Press, Hyderabad. 
[15] Lane, D. J. (1991): 16S/23S rRNA Sequencing. - In: Stackebrandt E, Goodfellow M, (eds.) Nucleic Acid Techniques in Bacterial Systematics. John Willey and Sons, New York.

[16] Lanyi, B. (1987): Classical and rapid identification methods for medically important bacteria. - Methods Microbiol 19: 1-67.

[17] Lee, D. H., Choi, S. L., Rha, E., Kim, S. J., Yeom, S. J., Moon, J. H., Lee, S. G. (2015): A novel psychrophilic alkaline phosphatase from the metagenome of tidal flat sediments. - BMC Biotechnol 15: 1. DOI: 10.1186/s12896-015-0115-2.

[18] Lewenza, S., Gardy, J. L., Brinkman, F. S., Hancock, R. E. (2005): Genome-wide identification of Pseudomonas aeruginosa exported proteins using a consensus computational strategy combined with a laboratory-based PhoA fusion screen. Genome Res 15: 321-9.

[19] Morita, R. Y., Moyer, C. L (2001): Origin of psychrophiles. - In: Levin, S. A., Colwell, R., Dailey, G., Lubchenco, J., Mooney, H. A., Schulze, E. D., Tilman, G. D. (eds.) Encyclopedia of Biodiversity. Academic Press, New York.

[20] Nei, M., Kumar, S. (2000): Molecular Evolution and Phylogenetics. - Oxford University Press, Oxford.

[21] Pratt-Lowe, E. L., Geiger, R. M., Richardson, T., Barrett, E. L. (1988): Heat Resistance of alkaline phosphatases produced by microorganisms isolated from California Mexican-style cheese. - J Dairy Sci 71: 17-23.

[22] Reysenbach, A. L., Pace, N. R., Robb, F. T., Place, A. R. (1995): Archaea: A Laboratory Manual-Thermophiles. - CSHLP Protocol 16: 101-107.

[23] Seufferheld, M. J., Alvarez, H. M., Farias, M. E. (2008): Role of polyphosphates in microbial adaptation to extreme environments. - Appl Environ Microbiol 4: 5867-74.

[24] Simbert, R. M., Krieg, N. R. (1994): Phenotypic Characterization. - In: Gerhardt P., Murray R., Wood W., Krieg N. R. (eds.) Methods for General and Molecular Bacteriology. American Society for Microbiology, Washington DC.

[25] Stadtländer, C. (2007): Scanning Electron Microscopy and Transmission Electron Microscopy of Mollicutes: Challenges and Opportunities. - In: Méndez-Vilas A., Díaz J., (eds.) Modern Research and Educational Topics in Microscopy. Formatex, Badajoz, Spain.

[26] Struvay, C., Feller, G. (2012): Optimization to low temperature activity in psychrophilic enzymes. - Int J Mol Sci 13: 11643-65. DOI: 10.3390/ijms130911643.

[27] Tamura, K., Dudley, J., Nei, M., Kumar, S. (2007): MEGA4: Molecular Evolutionary Genetics Analysis (MEGA) software version 4.0. - Mol Biol Evol 24: 1596-9.

[28] Thompson, J. D., Higgins, D. G., Gibson, T. J. (1994): CLUSTAL W: Improving the sensitivity of progressive multiple alignment through sequence weighting, position specific gap penalties and weight matrix choice. - Nuc Aci Res 22: 4673-80.

[29] Tsuruta, H., Mikami, B., Higashi, T., Aizono, Y. (2010): Crystal structure of cold-active alkaline phosphatase from the psychrophile Shewanella sp. - Biosci Biotechnol Biochem 74: 69-74.

[30] Vincent, J. B., Crowder, M. W., Averill, B. A. (1992): Hydrolysis of phosphate monoesters: a biological problem with multiple chemical solutions. - Trends Biochem Sci 17: 105-10. 